\begin{tabular}{ll} 
Balkanologie & Balkanologie \\
\cline { 1 - 2 } & Revue d'études pluridisciplinaires
\end{tabular}

Vol. XI, $n^{\circ}$ 1-2 | 2008

Volume XI Numéro 1-2

\title{
Serbia 2000-2008: a changing political culture?
}

Ivana Spasić

\section{(2) OpenEdition}

\section{Journals}

Electronic version

URL: http://journals.openedition.org/balkanologie/1282

DOI: 10.4000/balkanologie.1282

ISSN: 1965-0582

\section{Publisher}

Association française d'études sur les Balkans (Afebalk)

\section{Electronic reference}

Ivana Spasić, «Serbia 2000-2008: a changing political culture? », Balkanologie [Online], Vol. XI, n 1-2 | 2008, Online since 31 December 2008, connection on 17 December 2020. URL : http://

journals.openedition.org/balkanologie/1282 ; DOI : https://doi.org/10.4000/balkanologie.1282

This text was automatically generated on 17 December 2020.

(c) Tous droits réservés 


\title{
Serbia 2000-2008: a changing political culture?
}

\author{
Ivana Spasić
}

\section{Introduction}

1 The aim of this paper ${ }^{1}$ is to indicate some trends in the changing political culture in Serbia from the point of view of ordinary citizens. Discussions of political and economic transitions in Eastern Europe have tended to privilege the top-down approach, presenting general outlines and macro-processes. This paper on the contrary starts from the assumption that this must be complemented by a more bottom-up, finegrained view that takes seriously what ordinary people think and say about what is going on. The choice is methodological and does not imply that what citizens think is necessarily "correct" in cognitive or moral terms. There is just the belief that, in a democracy, the real, living people, with all their virtues and vices, must be taken into account since they are the true basis of any political processes and the source of their legitimacy.

2 The main database I draw on has been collected by the long-term qualitative study "Politics and everyday life". This project, conducted in three successive waves between 2002 and 2007, applied the method of semi-structured interviews and centered on topics of political transition and social transformation in Serbia. The idea was to look for connections between people's everyday life and their evaluations of the political developments in the Serbian society. Ordinary people of different backgrounds and living in different places were interviewed. ${ }^{2}$ The project was not a true panel study, since not exactly the same people were interviewed (although there are a handful of them who took part in all three stages). The sample varied in size and composition following the slightly different objectives of the three studies, and the topics included in the interview guide were not identical. The most important difference in the character of the sample, apart from its size, was that in the first study both politically active and passive citizens were targeted, both supporters and opponents of the change 
of regime in 2000, while in the other two studies this provision was not strictly applied, the result being a slight overrepresentation of respondents with a pro-democratic orientation. In terms of breadth, the first study broached the largest number of issues, while in 2007 we focused specifically on electoral abstention. For all these methodological reasons, the findings are not strictly comparable, but there are trends which, with all the necessary caution, can be roughly traced and followed through all three stages.

3 In addition to these data I will use other sources as well, mainly quantitative and "objective", like election results, public opinion polls etc. Comparisons of this sort can be very helpful in reconstructing whether and how the political culture of Serbian citizens has been evolving over the past eight years.

One more note is in order at the very beginning: I will not discuss at all the issue of Kosovo and the huge impact Kosovo's declaration of independence on February 17, 2008 has had on Serbian politics, because I am basing my analysis on data collected well before the event. Moreover, the question is too complex to be dealt with summarily.

\section{The "Great Shift": 2002 Findings}

5 Let me first summarize briefly the main findings of our first study, since they will be used as the baseline against which to assess the developments in the meantime. The 2002 interviews showed that attitudes of Serbian citizens toward politics in general, political change of 2000, new post-Milošević government and the problems Serbia was facing were marked by a positive change as compared with the kind of political behavior (most) Serbs had engaged in during late 1980s and early 1990s. In our first publication we called this shift "New Realism" and found its manifestations in increased prominence of elements such as rational reasoning, down-to-earthness, tolerance, moderation etc.

6 The first and most obvious corroboration is provided by the very events of October 5 , 2000: hadn't Serbian citizens changed, they would not have been capable of staging such a massive yet disciplined protest, and probably would not have succeeded in toppling Milošević. Not surprisingly, this event occupied central place in 2002 interviews, and the way people described it provided a focal point for articulating the new political values. The "meanings of October 5 " extracted from respondents' accounts may be summarized as follows: 1) It was a historical event and a turning point in recent Serbian history; 2) The victory was won by the joint struggle of united citizens; 3) It marks the beginning of a radical change in all aspects of life - "we must build our common house anew", as dozens of them put it; 4) This was popular defense of one's right to vote freely - votes are sacred in a democracy; 5) Risks were high but people went out anyway, because they could not be intimidated any more. It is important to stress that this characterization of "October 5 " was basically the same across political groupings - even those who in principle opposed the political change were ready to concede this set of features to the event itself and fundamentally accepted its consequences (as inevitable, if not desirable). We shall see how this, too changed in later years.

7 At that initial moment of the post-Milošević era, citizens had quite distinct ideas about what the new government had to do first. These ideas apart from substantive contents 
also included a strong normative component, and so may be called "normative expectations":

-1. Economic recovery: more jobs, higher pay, better living standards;

-2. Equality before the law and legal security: no impunity for anyone, a functioning legal system, protection of rights;

-3. Institutional rules: eliminating corruption, general regularization of procedures in state institutions;

-4. Depoliticization of life chances: political memberships, preferences or activities must not influence a person's non-political well-being (as it had been customary all the time since 1945);

- 5. Caring for the common good instead of partisanship.

Finally, here is a list of integral elements of "New Realism" along with two accompanying shifts in attitudes to the political sphere:

\section{New Realism}

- rationality: when assessing a situation, one has to be reasonable, take into account the objective circumstances and weigh the possibilities;

- rejection of war as a means to achieve political goals: war must be avoided, negotiations are always better no matter how difficult the problem;

- suspicion of "fast and easy" solutions, premium on pragmatism and compromise: lasting solutions are hard and slow to come by, one has to be patient;

- normal life as politicians' mandate: those in power ought not to fulfill grand missions, but simply to provide conditions so that people can live normally

- openness to the world: Serbia must never be isolated again

2. Democratic threshold: government is accountable to the voters (not God-given), changeable (not there forever), and changed by popular vote (not by force)

11 3. Ambivalence of the political: the ambiguous valences ascribed to the political sphere

- - bad politics/good politics: politics is devil's business and decent people should avoid it any price; "good" politics also exists (it means making responsible and wise decisions determining the course a society takes) but not in Serbia - maybe not anywhere actually...

- - the paradox of (non)involvement: politics is dirty, parties are trash, I want them out of my life but we, the people must remain involved in order to control the government.

We argued in our first study that the events of 2000 were due to a process of social learning, whose subject was the Serbian polity. As a political community, citizens of Serbia had taken some lessons from the bitter experience of the 1990s, and were putting these lessons - an 'emergent political culture' - to practice. We also argued that these changes in political outlook could serve to preclude a possible reverting to the past. The 1990s would never return again. People have developed a strong suspicion, perhaps even a sort of immunity, to demagogic and populist appeals. They had learned the hard way what their price was.

However, what happened in Serbia since that time seems to have taken a very different direction. Most of the events after 2002, including political behavior of citizens at some critical junctures, seem to prove our whole analysis wrong - overly optimistic and misplaced. What I will try to do in the rest of this article is to defend at least some of our previous conclusions. I believe that at least some of our arguments are still valid, but provided they are placed in a context. I wish to look at the period after 2002 at two 
levels simultaneously - the level of political actors, to see what of the citizens' "normative expectations" they have accomplished, and the level of citizens' attitudes and conduct, to see what parts of the emergent political culture have been preserved.

\section{The Mixed Destiny of Collective Lessons}

14 The collective lesson that has undoubtedly survived into 2005 and 2007 is the democratic threshold - the idea of changeability of government through elections. Elections and voting have become thoroughly normalized. Hardly anyone questions their necessity or democratic capacity anymore. The normal life demanded from politicians (subpoint of New realism) survived too: a government's value is steadily measured in rational terms, by the visible and tangible results it has produced. What counts is the performance, the efficiency demonstrated by holders of executive offices, and not their personality traits, charisma, or ideological congeniality, as it had been quite usual before.

Such positive developments were reinforced by some new points that have emerged in the later studies. One of these is acceptance of political pluralism (obviously related to the democratic threshold). This mood, increasingly prominent through 2005 and 2007, is most easily measured negatively - by the declining frequency of expressed aversions to the political system based on free competition among different political parties. $^{3}$ Another new point is emotional defusing of the way people talked about politics. This was to be expected, as euphoria naturally subsides with time. This is in turn connected with new realism, since it implies less passion and less ideology in people's political judgments, to the benefit of normal life and performance as expected from officials.

16 Another interesting point was also increasingly felt in the later studies: individualism. The impression is that more and more often people assume self-consciously (though not always gladly) the attitude of "minding their own business", taking care of themselves and their families, instead of waging historical wars for some larger-thanlife goals (betterment of the nation, improvement of democracy, national pride, etc.). Concentrating their energies on their self-growth and small-scale interests may be discounted as unwelcome "privatization", but it may also be interpreted as healthy development of an individualistic stance, so much missing from the Serbian historical and cultural tradition.

Unlike the foregoing "collective lessons" that have more or less survived, many more of them have become quite shaky - if not totally destroyed, then certainly seriously threatened. The most obvious candidates are rationality, rejection of war and suspicion of fast solutions. All of them seem to be thoroughly refuted by the revival of the ancien regime political forces more specifically, the Serbian Radical Party (SRS). For, everything about the SRS - from the values it promotes to its records in power and outside of it to the public manners of its officials - is the direct opposite of these "collective lessons" as we identified them. So if the citizenry really took these lessons, as we claimed, how is SRS's success to be explained?

From its near-disappearance in 2000, the SRS returned to the political scene and is continuously improving its ratings in elections and public opinion polls. For the first 
time it emerged as the strongest single party in parliamentary elections of December 2003.

Table 1. Parliamentary elections 2003

\begin{tabular}{|l|l|}
\hline G17 PLUS & 11.46 \\
\hline SERBIAN RADICAL PARTY (SRS) & 27.61 \\
\hline DEMOCRATIC PARTY OF SERBIA (DSS) & 17.72 \\
\hline DEMOCRATIC ALTERNATIVE & 2.20 \\
\hline DEMOCRATIC PARTY (DS) & 12.58 \\
\hline SERBIAN RENEWAL MOVEMENT/NEW SERBIA & 7.66 \\
\hline OTPOR & 1.63 \\
\hline FOR PEOPLE'S UNITY & 1.79 \\
\hline SOCIALIST PARTY OF SERBIA (SPS) & 7.61 \\
\hline INDEPENDENT SERBIA (Vladan Batić) & 1.18 \\
\hline TOGETHER FOR TOLERANCE (Nenad Čanak) & 4.22 \\
\hline YUGOSLAV LEFT (JUL) & 0.09 \\
\hline
\end{tabular}

Source: Statistical Office of the Republic of Serbia,

http://webrzs.statserb.sr.gov.yu/axd/en//zbori/izbori1.php?ind=1

19 In this table, parties winning below 1\% are omitted, with the exception of the Yugoslav Left - the once all-powerful party of Milošević's wife. This is meant to illustrate the fact that not all ancien regime parties experienced a renaissance: as may be seen, JUL was virtually wiped out, while SRS soared.

Next year, in presidential elections, SRS candidate Tomislav Nikolić entered second round, to be defeated, by not too great a margin, by the Democrat Boris Tadić $(53.24 \%$ : $45.40 \%)$. The trend continued in 2007 parliamentary elections, when SRS fared even better than in $2003-28.6 \%$ of votes and 81 seat in the National Assembly, that is 17 seats more than the next strongest party, the Democratic Party (DS). The parties of the so-called "democratic bloc" however managed, after long months of difficult negotiations seasoned with fights and scandals, to agree on a majority cabinet that excluded the SRS. (This government fell in March 2008 on the Kosovo problem, but that is another story.) Finally, the repeated contest between the same rivals in February 2008 presidential elections was even more uncertain to the very end (first round: Nikolić $39.99 \%$ : Tadić $35.39 \%$; second round Tadić $50.5 \%$ : Nikolić $47.3 \%$ ).

21 My suggestion here is that the renewed attraction of SRS may not necessarily be interpreted as a collapse of all the improvements and "collective lessons" identified in the early 2000s: perhaps unfortunately, the SRS has profited from some aspects of the 
transformation of Serbian political culture. The newly found rationality of the Serbian electorate which is a guarantee of its democratic future has also contributed to the success of the Radicals - partly because this rationality is itself insufficiently stabilized, and partly due to the unfavorable objective constellation. I will try to substantiate this claim in the following sections.

To begin with, the current support to SRS is not of the same kind as the mass craze centered on Milošević in the late 1980s, the infamous "anti-bureaucratic revolution" as his ideologues named it, which was hotly emotional, passionate, and ideological - in a word, irrational. Though the two phenomena may share some of the same sources (like similar values, worldviews, and cultural moods), in SRS followers one does not see deluded people, tricked into believing everything they are told by a collection of bizarre, megalomaniac figures. The support to SRS is more interested-based and interest-driven, more "down to earth", and therefore more "rational", if we take this word in its most elementary sense of weighting one's chances and having articulable reasons for what one does i.e. chooses.

For illustration, take the correlation of party preference and replies to the following question in a survey: Taking into account life as a whole, would you say you have been predominantly a winner, a loser, or a little of both? The distribution of "winners" and "losers" according to political parties the respondents like clearly shows how political orientation depends on the subjective experience of transition.

Table 2. Experience of being a loser and party preference

\begin{tabular}{|l|l|l|l|l|}
\hline & Winner & Loser & Both & Total \\
\hline DS & 27 & 15 & 58 & 100 \\
\hline SRS & 4 & 47 & 49 & 100 \\
\hline No preference & 8 & 29 & 63 & 100 \\
\hline Average & 12 & 30 & 58 & 100 \\
\hline
\end{tabular}

Source: Mihailović 2006: 61

From the figures it is clear that SRS base is located mostly among the so-called transition losers. These people believe (quite realistically) that, given their unfavorable profile (advanced age, lower education, rural residence...), their chances in an open capitalist competition are rather slim. So they opt for a corporative, nationalist state that will protect them - for a closed economy and egalitarianism promised by the SRS.

The correlation becomes even more striking if to this personal pessimism we add the experience of total, collective loss, operationalized by the question: Taking into account all that has been going on over the past 4-5 years, do you see our country as a winner, a loser, or a little of both? The following table presents correlations of the "combined loss index" with attitudes to democracy (respondents answering "Agree" to the listed statements): 
Table 3. Experience of general loss and attitudes to democracy

\begin{tabular}{|l|l|l|l|l|}
\hline & winner & loser & both & $\begin{array}{l}\text { don't } \\
\text { know }\end{array}$ \\
\hline Democracy is better than any other form of government & 77 & 30 & 45 & 18 \\
\hline $\begin{array}{l}\text { For people like me, democratic and undemocratic regimes are } \\
\text { the same }\end{array}$ & 8 & 17 & 14 & 10 \\
\hline $\begin{array}{l}\text { Sometimes an undemocratic government is better than a } \\
\text { democratic one }\end{array}$ & 7 & 30 & 18 & 13 \\
\hline Don't know & 8 & 23 & 23 & 59 \\
\hline Total & 100 & 100 & 100 & 100 \\
\hline
\end{tabular}

Source: Stoiljković 2007: 29

While the above measures are subjective (respondents themselves decided whether they are classified as winners or losers) the connection between SRS vote and being located on the lower rungs of the social ladder is also visible if we use objective variables, like education:

Table 4.Education and announced vote in presidential elections 2008 , 2nd round

\begin{tabular}{|l|l|l|l|}
\hline & Nikolić & Tadić & Average \\
\hline Elementary school & $27 \%$ & $16 \%$ & $24 \%$ \\
\hline Trade school & $17 \%$ & $7 \%$ & $11 \%$ \\
\hline \hline Secondary school & $45 \%$ & $52 \%$ & $48 \%$ \\
\hline College or university & $11 \%$ & $25 \%$ & $17 \%$ \\
\hline \hline Total & $100 \%$ & $100 \%$ & $100 \%$ \\
\hline
\end{tabular}

Source: CeSID, January 2008

27 To conclude: subjective "winners", the better educated, and respondents who see their family's standard of living as "fair" to "middle" opt predominantly for democratic parties. The latter thus tend to politically represent the "winners", and the former the "losers". The correlations are quite high, especially with the combined "loss index"4.

28 The message of these figures is clear: the greater the number of people who feel they are profiting from the current social transformation, the firmer the democracy. In other words, without rapid and powerful economic improvement democracy in Serbia is not likely to be stabilized soon. This is not the only condition, but it is a major one. 
29 Further support to the claim that current popularity of the SRS has rational grounds may be obtained if we concentrate on the trajectory of the normal life component of the new realism collective lesson from 2002, and the concomitant performance criteria for assessing politicians in power. These lessons have survived: in our 2005 and 2007 studies this way of judging the authorities at all levels of government was ever more prominent, even becoming routinized. Yet here this gain for a new political culture acts as a double-edged sword. Let us first make a detour through the way people listed societal priorities, that is, the most important things that ought to be achieved in Serbia. The questionnaire item was: Which aspirations and goals should be achieved in order for Serbia to become a society you would like to live in? Choose three and rank them.

Table 5. Priorities for Serbia in the opinion of citizens

\begin{tabular}{|l|l|l|l|l|}
\hline & $\% 2003$ & Rank 2003 & $\%$ 2005 & Rank 2005 \\
\hline Decent living standards & 57 & 1 & 63 & 1 \\
\hline Good employment opportunities & 42 & 2 & 46 & 2 \\
\hline Minimum crime and corruption & 36 & 4 & 41 & 3 \\
\hline Rule of law & 40 & 3 & 37 & 4 \\
\hline Political stability & 26 & 6 & 35 & 5 \\
\hline Successful economy & 33 & 5 & 33 & 6 \\
\hline Well functioning democracy & 14 & 7 & 14 & 7 \\
\hline Social justice & 14 & 8 & 13 & 8 \\
\hline Accomplishment of national goals & 6 & 9 & 7 & 9 \\
\hline
\end{tabular}

\section{Source: Mihailović 2006: 59}

We can see how the effect of the performance criteria is double-edged: on one hand, it is undoubtedly positive that citizens have gotten used to applying the measure of efficiency to evaluate political figures; this is a sign of a more rational (should I say more "Western-like"...) political culture. But on the other hand, it is only the democratic parties that have been in power after 2000; in this way they were exposed to being judged by the electorate along these lines. And the dissatisfaction with the results they achieved - which, though not negligible, are certainly not fantastic makes many people turn to the SRS reasoning that, maybe, the SRS would "do better". ${ }^{5}$

One more detail is interesting to note in Table 5: the low rating of "Accomplishment of national goals". It may seem bizarre that in the (presumably) very nationalistic Serbian public opinion this collective goal was twice ranked the last and got just 6-7 percent of support. This change of mood amongst the Serbian electorate has been registered for some years and, of course, the SRS strategists know it very well. So it is not accidental 
that this party has lately taken pains to "polish" its public image, to soften its rhetoric, and to shift the accent from national to social topics. Thus for a couple of years already the SRS is insisting on pro-social security, anti-privatization, anti-globalist and egalitarian messages. Though not left out of course, chauvinism is no longer foregrounded in their public image.

\section{The disenchantment: was it inevitable?}

Unlike the optimistic, sometimes euphoric mood that dominated our first interviews, what prevailed in 2005 and, especially, 2007 is the gloomy tone of disappointment and disillusionment. When talking about how they felt, and how people around them felt, interviewees said that hopes were dashed, that there was nothing to be expected any more. In 2002 people were saying they knew that change could not happen overnight and that they were ready to wait for life to get better in Serbia. Three years later, they were still in principle patient, though stating that they no longer knew how much longer this improvement would take. And in 2007, they stopped waiting altogether: there was nothing to wait for, they said. Or, as Golubović6 summarized it: until 2005, people were dissatisfied with the pace of changes; from 2005 on, they are no longer sure as to the direction of changes. In the beginning, they used to say "it's generally OK, but the government could do things more quickly"; later on, this was replaced by fundamental doubt: "I'm not sure where Serbia is going".

Disenchantment was routinely registered in all post-communist countries, after the brief period of initial euphoria. But is it perhaps specific in Serbia? Is it more intense, or in some other ways different? What are its primary causes?

To begin with, some of people's normative expectations listed above remained unfulfilled. First, economic recovery did not really take place, or at least not to the extent most people deemed necessary ${ }^{8}$. It could be argued that in economic matters actors' performance is strongly dependent on objective circumstances, and the Serbian economic policy makers faced a very unfavorable situation indeed, having to distribute extremely scarce resources to many equally deserving priorities.

But economy is not the whole story and many things that could have been done at little or no cost, were not achieved, or not completely. Most of these concern the strictly political sphere and the conduct of political actors. Let us see what happened with the demand for depoliticization of life chances. While an individual's political orientation no longer brings direct risks to life and limb - as it did under Milošević - Serbia is still much of a "party-state", only pluralized. Party membership is crucial for appointments, often even for getting a simple job or some other benefit. Political parties, interviewees say, do not represent actually existing social groups or identifiable ideological positions but on the contrary try to divide up the society in accordance with their own pursuits. They develop clientelism: instead of breaking once and for all with Milošević's practice of choosing people for political offices at all levels of government and in governmentcontrolled enterprises on the basis of political obedience and personal loyalty rather than expertise and capability, the democratic parties have continued doing just the same. Within the parties, one cannot speak one's own mind - uncritical false unanimity is fostered instead of critical reflection and individual integrity.

The overcrowded and chaotic character of the Serbian party scene is confirmed by various data. One measurement of party positionings yielded a telling distribution 
along the Left-Right dimension: this distinction is shown to be virtually inapplicable here, since literally all parties are found at all positions, from Extreme Left to Extreme Right. The differences are just in percentages - and even they are not very large ${ }^{9}$. In our 2005 interviews, respondents often presented a reasonable and argued criticism of the existing political offer, pointing out that it was not clear at all which party stands for what kind of policy or values; who is a natural ally of whom, and who supports whom. The respondents called for a "clearing up" of the party scene, where likeminded parties would be grouped in recognizable blocs. ${ }^{10}$

The generalized criticism and rejection of the totality of the political sphere (political leaders, parties, parliament, government bodies...) sharpened over time in our interviews. After a certain rapprochement between "ordinary people" and "politicians", as a result of the joint struggle in 2000 , the gap soon widened again. The aversion to politics has lead either into utter passivization, or into bitter resentment (To the issue of personal involvement I will return below.) But ironically, the individualism noted above as one of the new motifs appearing in the later studies arises precisely in connection with this depressed mood. As people stopped believing political change would make any sensible positive impact in their lives, they started to look away from the political sphere at themselves and their small private worlds, searching them for possible strengths and assets. That is increasingly their choice, although they might not be very convinced it will work. Whether from the general perspective of democracy in Serbia this is more of a "negative" or a "positive" development, is difficult to judge.

The next extremely important expectation that has been betrayed is caring for the common good. Against the backdrop of citizens' emphatic belief that, after the new beginning of October 2000, everybody had to contribute to the benefit of the community (cf. "building our common house anew"), the behavior of political parties stands out in sharp contrast. For, they acted in exactly the opposite way, engaging in continuous mutual quarrels and conflicts, never putting particularistic differences and interests behind the interests of all. Unashamed partisanship played out in various public arenas, from the parliament to the media, disgusted the citizens (once again). A remarkable instance of the political elite's inability to operationalize the common interest is their failure to agree upon a new Constitution until October 2006. This indicates their unwillingness to take seriously the institutionalization of democracy and their detrimental disregard for the chances provided by the moment of symbolic hegemony of the "democratic side" in the immediate aftermath of October 5.11

However, as already noted in relation with growing individualism, such developments often carry ambiguous potentials. What is destructive from one point of view may hold out a promise from another. So despite the bleak picture of life in Serbia our interviewees were describing in 2005 and 2007, what slowly emerged in the background was a sort of state and social system that, very gradually and very insecurely, was beginning to function. This institutional infrastructure that was being put together piece by piece might not meet anybody's expectations in terms of performance and quality of services, but still, it 'worked' in a way. Though the respondents criticized much of what this system was doing, these very criticisms were an indirect proof that there was something to criticize in the first place. In 2005 I termed this paradoxical situation "low normalization", to denote the inchoate sense that Serbia was slowly becoming something of a "normal" society. The depth of disappointment expressed by 
our interviewees was proportionate to the unrealistically high hopes they had invested in the "new beginning" of 2000; but these in turn, with their strong emotions and the feeling of total freedom in choosing the collective future (building our common house anew) had its price. Everything seemed possible just because everything had been ruined.

\section{Disengagmenet and electoral abstention}

A consequence of all these processes has been the extremely low esteem that political parties, political figures and the whole political system enjoy in the eyes of citizens. The strong rejection of the party system has also resulted in declining rates of voter turnout from one election to another. Shrinking electoral participation has become a concern in recent years, especially in the "democratic camp". Various actions have been undertaken to, first, study the phenomenon and, secondly, to reverse the trend ${ }^{12}$. The issue is complex however. Here objective facts mingle with political fears. For one thing, abstention has actually not been so high as was believed. CeSID data measuring voter turnout show a vacillating line, not at all unlike what one finds in other countries. It has ranged around 50-60\%, with quite explicable lows (under $40 \%$ in failed presidentials in 2003) and highs (the decisive elections of 2000) ${ }^{13}$. Moreover, even these percentages must be corrected upwards, because the official electorate, for various technical reasons, is significantly larger than realistic. ${ }^{14}$

What actually caused concern was an indication consistently emerging from studies since the late 1990s, that in addition to "structural" or "sociological" abstainers (those who are too sick, too old, too poor, and generally too socially alienated to vote) there was also the other kind - a significant part of the younger, urban and relatively well educated electorate tending to the democratic option that didn't vote, thereby contributing to the good score of the SRS. The reasons were located within these young people's general apathy and/or dissatisfaction with the behavior of democratic parties. One of the first students of the phenomenon coined the phrase "abstainers against the façade democracy" and interpreted this kind of abstention not as a sign of political apathy but on the contrary of the critical stance aimed at the way the existing parties operationalized the democratic option ${ }^{15}$. Although of course this group does not comprise all the abstainers, their numerical share is obviously not negligible since their attitudes color significantly the general picture of the whole category of abstainers. For instance, one poll has found clear divergences in terms of values between abstainers (in general) and voters: the former had a more marked democratic and pro-European attitude than the latter, but at the same time were more disheartened and more pessimistic. ${ }^{16}$

The 2008 presidential elections seemed to refute the growing apathy hypothesis: turnout was well over $60 \%$ (and even higher, in real terms). But this fits very well in what our 2007 interviewees told us: they said they would give up their abstention if the vote was clearly decisive. Obviously, these presidential elections, especially their second round, were felt to be just that - an occasion when Serbia was choosing its future, between two distinct and opposed options. Moreover, there is some indication that the belief in more frequent abstention of young, democratically minded people hadn't been totally unfounded: the turnout was considerably higher, and Tadić's score as well, in the second round. 

that a genuine social democratic option is missing. This may seem strange, since postsocialist transition structurally demands and produces this political supply, but on the other hand it is not strange at all, since in most other post-socialist countries this place is occupied by the reformed communists, while in Serbia the communists never underwent any true reform, they just changed the party name. But what is almost never is that the conservative option is equally missing - conservative in the conventional European sense of center-right, voelkisch politics, like the German Christian Democrats, French conservatives or, closer to home, HDZ in Croatia after 2000. Among Serbian parties, it is Koštunica's DSS that is best suited for this role. And they do play it to some extent, but the extent is really quite modest. The DSS hasn't grown into a respectable party with a clear profile, remaining instead a fuzzy catch-all which appeals to everybody and nobody in particular. It lacks a developed infrastructure and virtually any recognizable and strong personalities apart from Koštunica himself. ${ }^{17}$ There are, I believe, sizeable segments of the Serbian population who would, "naturally" as it were, tend to this party - elderly, traditionalist people, a 
bit slow and outmoded, with a strong national feeling but not fascist or openly authoritarian. Yet this segment of the electorate has not become attached to the DSS on a continuous basis; the party has not won their loyalty and the vote it gets is incidental and unstable. In the absence of sufficient pulls from DSS, most of these voters are likely to end up voting SRS. ${ }^{18}$

And finally, there is the issue of symbolic institutionalization of "October 5". How can we explain the fact that today, seven years after the event, it is possible to claim in public - as the SRS is doing - that all evils in Serbia started in 2000: from poverty and unemployment to hurt national pride and international powerlessness? That is, how is it possible to find people to believe it? And how come many among these believers themselves participated in the people's revolution of 2000? The answer lies in the neglect of the symbolic aspect of politics amongst the democratic forces. The "October 5" should have been institutionalized into a sort of new national holiday - if not literally, then at least figuratively; it could be remembered as a great date in recent Serbian history when citizens undertook their own collective political subjectivation. This symbolic crystallization could have channeled a portion of popular emotional energies away from celebrating aggressive nationalist symbols into celebrating democracy. This opportunity was not taken, and "October 5 " was almost immediately vulgarized and devalued by quarrels and mutual accusations of the democratic leaders. Hence it did not become forever fixed as a rupture between a "before" and an "after". The way was opened for later radical reinterpretations of what seemed to be clear to everybody - that the Milošević era was one of the worst periods in modern Serbian history. In our interviews, this process is also reflected, in the changing way our respondents talk about "October 5": in 2002, it was a historical date, the new dawn for Serbia etc. In 2005, it began to pale and sink down into the indistinguishable morass of "politics". In 2007, its mention makes people angry rather than proud, because they feel it to be the symbol of failed hopes and cheated promises.

\section{Conclusion}

So, is the Serbian political culture changing? Is it becoming more democratic, tolerant, reasonable? The answer depends on how much weight we ascribe to this variable. Political culture in its broad sense of diffuse sentiment, set of attitudes (never homogeneous) and symbolic patterns (not necessarily coherent) related to the definition and making of politics, is definitely changing. Yet it cannot stand on its own, without the support of an equally changing political structure of society. The evolving political culture needs to rely on a set of ever more stabilized institutions that serve as a framework for "doing politics" in ways different than before, in accordance with new, post-authoritarian rules. This other, objective and systemic side of the transformation of Serbian politics has played its part less well. Ordinary people have been, so to say, left alone to democratize their political outlook as best they can.

It is especially the democratically oriented citizens of Serbia that have been let down by "their" political representatives, the parties of the democratic bloc. The nationalists, supporters of authoritarian rule, and anti-Europeans have been much more satisfied with "their" champions - partly because they are, by definition, less demanding, and partly also because the democrats didn't care so much to attract and keep their own 
supporters. And from the mass of the undecided, most have either gone to the Radicals or into abstention rather than being drawn by the democrats.

In the conclusion to their recent book, two students of the Serbian political transition argue that, in 2007, Serbia is an electoral democracy, which means a democracy indeed (not an authoritarian or hybrid regime) but of an inferior kind ${ }^{19}$. It has not yet reached the level of liberal or constitutional democracy. In addition, it is neither fully consolidated nor in shambles, but instead "underconsolidated": it is functioning and the danger of a possible return to the past ways is not imminent, but not fully ruled out either. ${ }^{20}$ Democratic changes are visible and on the whole institutionalized, but are not absolutely irreversible. In the authors' opinion, the crucial and distinctive institution of electoral democracy is (truly) free and fair elections; and precisely this is taken to be the most important investment for the future democratic development of Serbia: "Free elections, as long as their outcomes are respected, have the capacity of producing political elites which each next time will build another brick into the democratic building, eventually bringing about a consolidated democracy in Serbia"21. Let us hope the building is erected and made to stand firm before another earthquake arrives.

\section{BIBLIOGRAPHY}

Bogosavljević, Srđan 2007. Odnos birača prema drugim strankama i koalicijama" [Attitude of voters toward other parties and coalitions], in: Lutovac (ed.), Birači i apstinenti u Srbiji, Beograd: FES/FPN/IDN, pp. 255-269.

CeSID, January 2008. Politički milje predsedničkih izbora II [The political ambience of presidential elections II], research report,

http://www.cesid.org/articles/download/files/Izvestaj,\%20Cesid,\%20januar\%202008..doc?id=60

Đurković, Miša (ed.) 2007. Srbija 2000-2006: država, društvo, privreda [Serbia 2000-2006: State, society, economy], Beograd: Institut za evropske studije.

Golubović, Zagorka, Ivana Spasić and Đorđe Pavićević (eds.) 2003. Politika i svakodnevni život: Srbija 1999-2002 [Politics and everyday life: Serbia 1999-2002], Beograd: IFDT.

Golubović, Zagorka 2005. "Rezultati demokratske tranzicije kroz prizmu građana Srbije 2005" [Results of democratic transition in the eyes of Serbian citizens], Filozofija i društvo 2 (27): 13-44.

Golubović, Zagorka (ed.) 2007. Probuđene nade - izneverena očekivanja [Awakened hopes - betrayed expectations], Beograd: Heinrich Böll Stiftung.

Golubović, Zagorka 2007a. "Angažovanost građana i apstinencija u postoktobarskoj Srbiji" [Citizens' engagement and abstention in post-October Serbia], in: Lutovac (ed.), Birači i apstinenti u Srbiji, Beograd: FES/FPN/IDN, pp. 63-80.

Jarić, Isidora 2005. "U kandžama izneverenih očekivanja" [In the claws of betrayed expectations], Filozofija i društvo 2 (27): 75-87. 
Kontić, Ljiljana 2007. "Privatizacija" [Privatization], in: M. Đurković (ed.), Srbija 2000-2006: država, društvo, privreda, Beograd: Institut za evropske studije, pp. 149-170.

Logar, Svetlana 2007. "Vrednosne orijentacije birača i apstinenata" [Value orientations of voters and abstainers], in: Lutovac (ed.), Birači i apstinenti u Srbiji, Beograd: FES/FPN/IDN, pp. 81-96.

Lutovac, Zoran (ed.) 2007. Birači i apstinenti u Srbiji [Voters and abstainers in Serbia], Beograd: FES/FPN/IDN.

Lutovac, Zoran (ed.) 2007a. Ideologija i političke stranke u Srbiji [Ideology and political parties in Serbia], Beograd: FES/FPN/IDN.

Marković, Vera 2006. "Promene vrednosnih orijentacija" [Changes in value orientations], in: Mihailović (ed.), Pet godina tranzicije u Srbiji II, Beograd: Socijaldemokratski klub/FES, pp. 219-227.

Mihailović, Srećko (ed.) 2005. Pet godina tranzicije u Srbiji I [Five years of transition in Serbia I], Beograd: Socijaldemokratski klub/FES.

Mihailović, Srećko (ed.) 2006. Pet godina tranzicije u Srbiji II [Five years of transition in Serbia II], Beograd: Socijaldemokratski klub/FES.

Mihailović, Srećko 2006. "Dugo putovanje u kapitalizam" [The long journey to capitalism], in: Mihailović ed. 2006, pp. 43-66.

Pantić, Dragomir and Zoran Pavlović 2007. Javno mnenje: koncept i komparativna istraživanja [Public opinion: the concept and comparative research], FES/IDN

Pavlović, Dušan and Slobodan Antonić 2007. Konsolidacija demokratskih ustanova u Srbiji posle 2000. godine [Consolidation of democratic institutions in Serbia after 2000], Beograd: Službeni glasnik.

Sajc, Aleksandra 2002. "Izborni apstinenti protiv fasadne demokratije: prilozi za razumevanje izbora u Srbiji" [Electoral abstainers against facade democracy: towards understanding elections in Serbia], Nova srpska politička misao Vol. IX(1-4): 47-66.

Sajc, Aleksandra 2007. "O značenju glasa kao činiocu izbornog ponašanja u Srbiji" [On the meaning of vote as a factor of electoral behavior in Serbia], in: Lutovac (ed.), Birači i apstinenti u Srbiji, Beograd: FES/FPN/IDN, pp.113-132.

Spasić, Ivana 2004. "Citoyens contre politiques: le 5 octobre 2000 et la construction de la Serbie de l'après Milošević", Revue d'études comparatives Est-Ouest, vol. 35, no. 1-2, mars-juin 2004: 269-295.

Spasić, Ivana 2005. "Politika i svakodnevni život u Srbiji 2005: Odnos prema političkoj sferi, promena društvenog poretka, javnost" [Politics and everyday life in Serbia 2005: views of politics, change of the social system, the public sphere], Filozofija i društvo 2 (27): 45-74.

Slavujević, Zoran 2007. Izborne kampanje: pohod na birače - slučaj Srbije od 1990. do 2007. godine [Election campaigns: fight for the voters, the case of Serbia 1990-2007], Beograd: FES/FPN/IDN.

Stoiljković, Zoran 2007. "Građani Srbije i demokratija - između nezadovoljstva i nepoverenja i uslovne i oročene podrške" [Citizens of Serbia and democracy - between discontent and distrust, and conditional and temporary support], in: Lutovac (ed.), Birači i apstinenti u Srbiji, Beograd: FES/ FPN/IDN, pp. 9-62.

Stojanović, Božo 2007. "Strana ulaganja - stanje i perspektive" [Foreign investments - situation and prospects], in: M. Đurković (ed.), Srbija 2000-2006: država, društvo, privreda, Beograd: Institut za evropske studije pp. 171-198. 
Vuković, Đorđe 2007. "Specifičnosti izborne apstinencije u Srbiji" [Particularities of electoral abstention in Serbia], in: Lutovac (ed.), Birači i apstinenti u Srbiji, Beograd: FES/FPN/IDN, pp. 133-150.

\section{NOTES}

1. The paper is part of the research project "Social Actors and Social Change in Serbia 1990-2010" (No. 149005), of the Institute of Sociological Research, Faculty of Philosophy in Belgrade, supported by Ministry of Science of Serbia.

2. Here is a brief description of the three stages: 1) Stage One, hereafter referred to as "2002 study": 300 interviews conducted in 19 cities between November 2001 and February 2002; the results published as: Golubović (Zagorka) et al., éds.,. Politika i svakodnevni život: Srbija 1999-2002 [Politics and everyday life: Serbia 1999-2002], Beograd, IFDT,.2003; for condensed findings in French see Spasić (Ivana), "Citoyens contre politiques: le 5 octobre 2000 et la construction de la Serbie de l'après Milošević", Revue d'études comparatives Est-Ouest, vol. 35, no. 1-2, mars-juin 2004: 269-295.; 2) "2005 Study": 30 interviews, 6 cities, February 2005, findings published in the special section of the journal Filozofija $i$ društvo (see Golubović (Zagorka), "Rezultati demokratske tranzicije kroz prizmu građana Srbije 2005" [Results of democratic transition in the eyes of Serbian citizens], Filozofija i društvo 2 (27): 13-44.; Spasić (Ivana), "Politika i svakodnevni život u Srbiji 2005: Odnos prema političkoj sferi, promena društvenog poretka, javnost" [Politics and everyday life in Serbia 2005: views of politics, change of the social system, the public sphere], Filozofija i društvo, 2 (27), 2005, pp.45-74.; Jarić (Isidora), "U kandžama izneverenih očekivanja" [In the claws of betrayed expectations], Filozofija i društvo 2 (27), 2005, pp.75-87. Also available online: http://www.doiserbia.nbs.bg.ac.yu/issue.aspx?issueid=194); 3) "2007 Study": 100 interviews, 10 cities, December 2006-January 2007, published as: Golubović (Zagorka), éd.,. Probuđene nade - izneverena očekivanja [Awakened hopes - betrayed expectations], Beograd, Heinrich Böll Stiftung, 2007.

3. Such opinions were by no means rare in 2002 interviews, especially among older respondents.

4. Mihailović (Srećko), éd., Pet godina tranzicije u Srbiji II [Five years of transition in Serbia II], Beograd: Socijaldemokratski klub/FES, 2006, p.62.

5. At that, it is somehow "forgotten" that the SRS was in power in the late 1990s, with disastrous results. This forgetfulness may be ascribed to the combined effects of people's strong focus on surviving in the present moment and disregarding everything else, and of successful SRS propaganda.

6. Golubović (Zagorka), "Angažovanost građana i apstinencija u postoktobarskoj Srbiji" [Citizens' engagement and abstention in post-October Serbia], in Lutovac (Zoran), éd., Birači $i$ apstinenti u Srbiji, Beograd: FES/FPN/IDN, p.71.

7. One should bear in mind though that the 2007 interviewees were extremely disillusioned and critical by research design, as precisely such subjects were sought. But they may differ from the average only in intensity or articulateness, not in the general mood, since the findings of other surveys undertaken in the last years concur with ours.

8. For an overview see Stojanović (Božo), "Strana ulaganja - stanje i perspektive" [Foreign investments - situation and prospects], in: M. Đurković (ed.), Srbija 2000-2006: država, društvo, privreda, Beograd: Institut za evropske studije, 2007, pp.171-198; Kontić (Ljiljana), "Privatizacija" [Privatization], in Đurković (M.), éd., Srbija 2000-2006: država, društvo, privreda, Beograd: Institut za evropske studije, 2007, pp.149-170. 
9. Bogosavljević (Srđan), "Odnos birača prema drugim strankama i koalicijama" [Attitude of voters toward other parties and coalitions], in Lutovac (Zoran), éd., Birači $i$ apstinenti u Srbiji, Beograd: FES/FPN/IDN, p.269.

10. In a sense, this is exactly what happened in the 'great split' of 2008 presidential and parliamentary elections (for better or for worse...).

11. This symbolic dominance is interestingly illustrated by a 2001 poll. Anxious to show their loyalty to the new government and the prevailing political climate, $70 \%$ of respondents said they had voted for DOS in the December 2000 republic elections. The problem is that this number is larger than the total voter turnout in the same elections! (see Logar (Svetlana), "Vrednosne orijentacije birača i apstinenata" [Value orientations of voters and abstainers], in Lutovac (Zoran), éd., Birači i apstinenti u Srbiji, Beograd: FES/FPN/IDN, 2007, p.85.) Our data confirm the hegemony of the "new spirit" prevalent throughout society in 2001-2002, when even opponents of the political change, as we saw, complied with its generally positive characterization.

12. Lutovac (Zoran), éd., Birači i apstinenti u Srbiji [Voters and abstainers in Serbia], Beograd: FES/ FPN/IDN, 2007, especially the papers by Sajc, Logar, Ristić, Vuković and Stoiljković. It is remarkable that this is the second collective volume (in addition to ours) devoted to the same topic that appeared in the same year. See also Slavujević (Zoran), Izborne kampanje: pohod na birače - slučaj Srbije od 1990. do 2007. godine [Election campaigns: fight for the voters, the case of Serbia 1990-2007], Beograd: FES/FPN/IDN., 2007; Pantić (Dragomir), Pavlović (Zoran), Javno mnenje: koncept $i$ komparativna istraživanja [Public opinion: the concept and comparative research], FES/IDN, 2007.

13. See Logar (Svetlana), "Vrednosne orijentacije birača i apstinenata" [Value orientations of voters and abstainers], in Lutovac (Zoran), éd., Birači i apstinenti u Srbiji, Beograd: FES/FPN/IDN, 2007, p. 82.

14. 6.5 instead of about 5.5 million, according to CeSID estimates (Vuković 2007).

15. Sajc (Aleksandra), "Izborni apstinenti protiv fasadne demokratije: prilozi za razumevanje izbora u Srbiji" [Electoral abstainers against facade democracy: towards understanding elections in Serbia], Nova srpska politička misao Vol. IX(1-4), 2002, pp.47-66.

16. Democratic pro-European orientation: abstainers $55 \%$ : voters $33 \%$; Pessimism: "Serbia is heading in a bad direction" - abstainers agree in $74 \%$, voters in $41 \%$; "There is no future for young people in Serbia" - $72 \%: 47$ \%, respectively (Logar (Svetlana), "Vrednosne orijentacije birača i apstinenata" [Value orientations of voters and abstainers], in Lutovac (Zoran), éd., Birači i apstinenti u Srbiji, Beograd: FES/FPN/IDN, 2007, pp.89, 93, 94).

17. DSS supporter has been found to lack any recognizable profile - differences within their corpus are greater than differences between the averages of this group and the supporters of other, very diverse parties (Marković (Vera), "Promene vrednosnih orijentacija" [Changes in value orientations], in Mihailović (Srećko), éd., Pet godina tranzicije u Srbiji II, Beograd: Socijaldemokratski klub/FES, pp.219-227, p.224).

18. Here is an illustration: in 2008 presidential election, the candidate DSS endorsed, their coalition partner Velimir Ilić, won only 7 percent. Evidently, most DSS-tending voters split between Nikolić and Tadić.

19. Pavlović (Dušan), Antonić (Slobodan), Konsolidacija demokratskih ustanova u Srbiji posle 2000. godine [Consolidation of democratic institutions in Serbia after 2000], Beograd: Službeni glasnik, 2007.

20. The parallel with what I termed "low normalization" is striking. The difference is in the analytic focus, not in substance.

21. Pavlović (Dušan), Antonić (Slobodan), Konsolidacija demokratskih ustanova u Srbiji posle 2000. godine [Consolidation of democratic institutions in Serbia after 2000], Beograd: Službeni glasnik, 2007, p.292. 


\section{ABSTRACTS}

The aim of this paper is to indicate some trends in the changing political culture in Serbia from the point of view of ordinary citizens. Discussions of political and economic transitions in Eastern Europe have tended to privilege the top-down approach, presenting general outlines and macroprocesses. This paper on the contrary starts from the assumption that this must be complemented by a more bottom-up, fine-grained view that takes seriously what ordinary people think and say about what is going on. The choice is methodological and does not imply that what citizens think is necessarily "correct" in cognitive or moral terms. There is just the belief that, in a democracy, the real, living people, with all their virtues and vices, must be taken into account since they are the true basis of any political processes and the source of their legitimacy.

L'objectif de cet article est d'indiquer certaines tendances dans l'évolution de la culture politique en Serbie, du point de vue des citoyens ordinaires. Les débats sur la transition politique et économique en Europe de l'Est ont eu tendance à privilégier l'approche "top-down", en présentant les grandes lignes et les macro-processus. Cet article, au contraire, part de l'hypothèse que cela doit être complété par une appoche du bas vers le haut, qui prend en compte ce que les gens ordinaires pensent et disent de ce qui se passe. Le choix est méthodologique et n'implique pas que ce que pensent les citoyens est nécessairement "correct" en termes cognitifs et moraux. Il y a juste la conviction que, dans une démocratie, les personnes réelles et vivantes, avec toutes leurs vertus et leurs vices, doivent être prises en considération, car elles sont le véritable fondement de tout processus politique et la source de leur légitimité.

\section{INDEX}

Geographical index: Serbie

Mots-clés: Culture politique

\section{AUTHOR}

\section{IVANA SPASIĆ}

Associate Professor. Department of Sociology - Faculty of Philosophy - University of Belgrade 